\title{
Managemnet of revegetation of the slag and ash deposits of the Paroseni Thermoelectric Power Plant
}

\author{
Andreea Cristina Tataru ${ }^{1 *}$, Aurora Stanci ${ }^{2}$, Dorin Tataru ${ }^{1}$, Mihai Sorin Radu ${ }^{1}$ and Ioan Rus ${ }^{1}$ \\ ${ }^{1}$ University of Petrosani, Department of Mechanical, Industrial and Transportation Engineering, 20 \\ Universitatii street, Petrosani, Romania \\ ${ }^{2}$ University of Petrosani, Department of Management, Environmental Engineering and Geology, 20 \\ Universitatii street, Petrosani, Romania
}

\begin{abstract}
As a result of the combustion of coal in the Paroseni Thermal Power Plant, large amounts of slag and ash waste are produced. Slag and ashes are deposited in the Caprisoara Valley slag and ash deposits. Upon completion of the deposit process, these landfills must be cleaned and reintroduced in natural circuit. An important step in the process of reintroduction in natural circuit of the deposits of slag and ashes is the implementation of some methods of revegetation. The chosen method must respect the main objectives of an environmental management system. In this paper we will present a method for managing the process of revegetation of the slag and ash deposits in order to reintroduce affected areas into the natural circuit.
\end{abstract}

\section{Introduction}

In recent years, environmental issues are an integral part of the strategy of companies around the world. Each economic unit strives to achieve and demonstrate, along with economic growth, a high level of environmental protection to comply with environmental legislation.

In this context, countries with high environmental standards are interested in protecting them from competitors in countries where they are less severe.

More than ever, it is recognized that effective pollution control cannot be achieved exclusively on technological solutions but must be addressed through an environmental management system integrated with the overall management of the company.

In many countries, the implementation of environmental management systems, although a voluntary action, has succeeded in convincing not only to the obtained financial benefits (such as: identifying areas that can bring savings, increasing production efficiency, finding new markets, etc.), but also by increasing creditworthiness in obtaining bank credits, attracting investors and new beneficiaries.

\footnotetext{
*Corresponding author: andreeastanci@yahoo.com
} 
In present, the company's focus on the introduction of environmental management systems (EMS) can be found at a global level. They provide a structured and systematic way of integrating environmental issues into all aspects of a company's business.

The goal is not only to comply with environmental legislation and minimize financial risks, but also to continually improve the environmental performance, thus ensuring a good image and a number of advantages in the competitive market.

\section{Data and Methods}

An environmental management system has as main objective to help a company in:

- identifying and controlling the environmental aspects, impacts and risks of the company;

- meeting the environmental policy objectives and targets, including compliance with environmental legislation;

- defining a set of core principles guiding future activities addressing environmental responsibilities;

- $\quad$ establishing increases in the company's environmental performance based on a cost-benefit balance sheet;

- determining the resources needed to achieve the objectives;

- defining the responsibilities, authority and procedures to ensure the involvement of each employee of the company in reducing the negative impact on the environment;

- establishing an efficient communication system inside the company and providing training for the staff. $[1,2]$

Industry throughout the world in its long existence has had and has negative effects on environmental factors. Today there is the problem of rehabilitation of areas affected by industry.

Slag and tailings dumps lead to significant problems in how they contribute to environmental pollution. These, upon completion of the filing process, should be rearranged and rendered in the natural circuit.

The tailings ponds are hydrotechnical constructions that are constructed as enclosures for tailings storage resulting from industrial production processes. They are also used for the storage of alluvial material resulting from dredging of waterways, decoltering of accumulation lakes, etc. Slag and ash are deposited in sedimentation tailings pond.

Reintroduction in the economic circuit of land affected by anthropogenic activities is based on a complex of redevelopment works of affected areas. [3]

Government Emergency Ordinance no. 195/2005 (approved by Law No. 265/2006) on Environmental Protection creates a legislative framework. This ordinance requires the redevelopment of the areas affected by anthropogenic activities after the completion of the works and the closure of the activities in the affected areas.

Reintroduction of the land degraded by anthropogenic activities into the economic circuit is carried out on the basis of a general planning plan. It must be drafted, discussed and approved by the local community and the law enforcement bodies on the basis of which the works are planned and carried out.

The choice of an ecological reuse is made according to the characteristics of the soil, the available resources, as well as the attitude of the owners and the local community.

In order to determine the chemical characteristics of the slag and ash in the settling ponds of the Paroseni Thermal Power Plant, laboratory chemical analyzes were performed. The analyzed samples were taken on the two compartments of the Valea Caprisoara pond and from the Emergency pond. The sampling points are shown in Figures 1-3. 


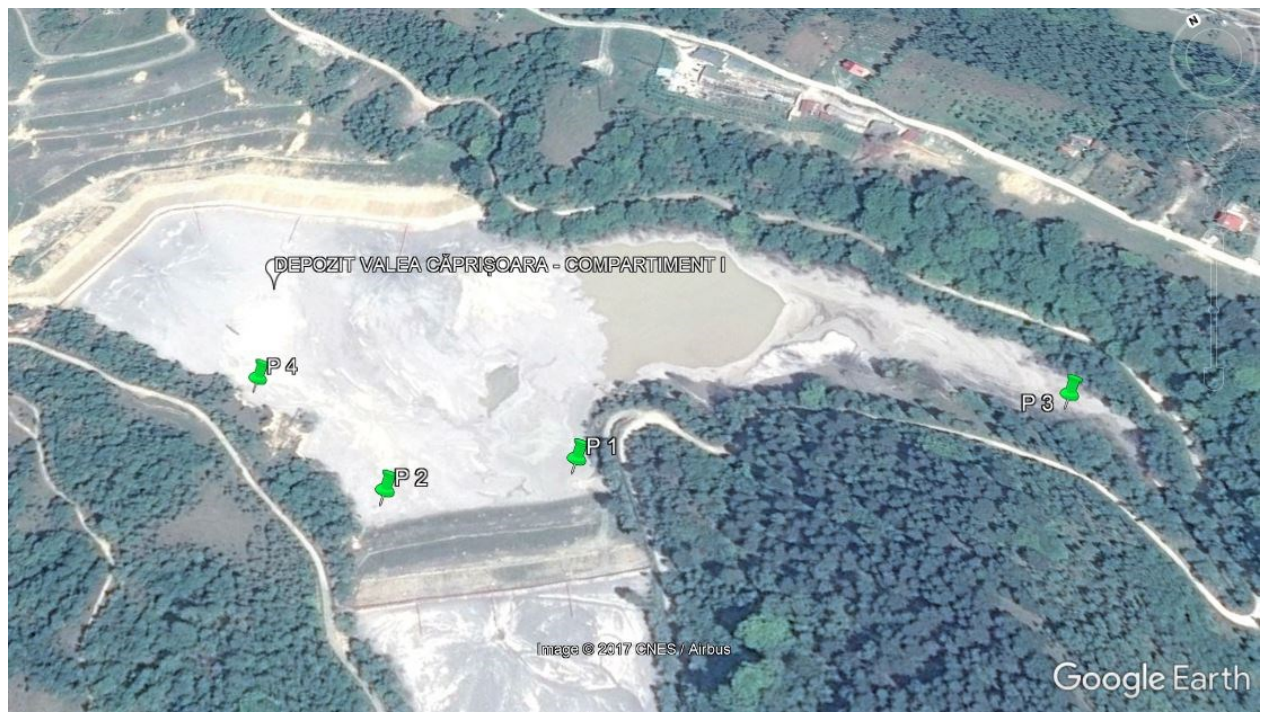

Fig. 1. The sampling points of the analyzed samples from the slag and ash deposit Valea Caprisoara compartment I

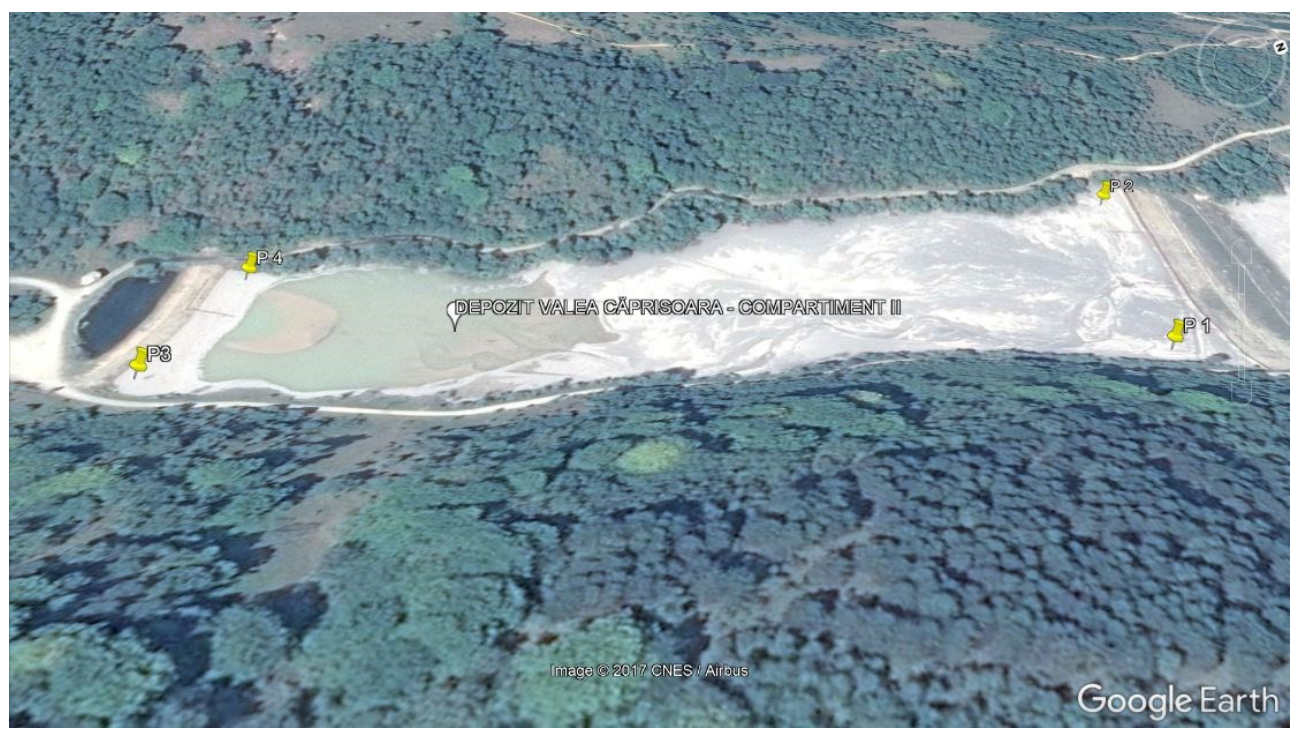

Fig. 2. The sampling points of the analyzed samples from the slag and ash deposit Valea Caprisoara compartment II

Chemical analyzes were also carried out for the slag and ash in the Emergency pond of the Paroseni Thermal Power Plant. The sampling points for the analyzed samples are shown in Figure 6.7. 


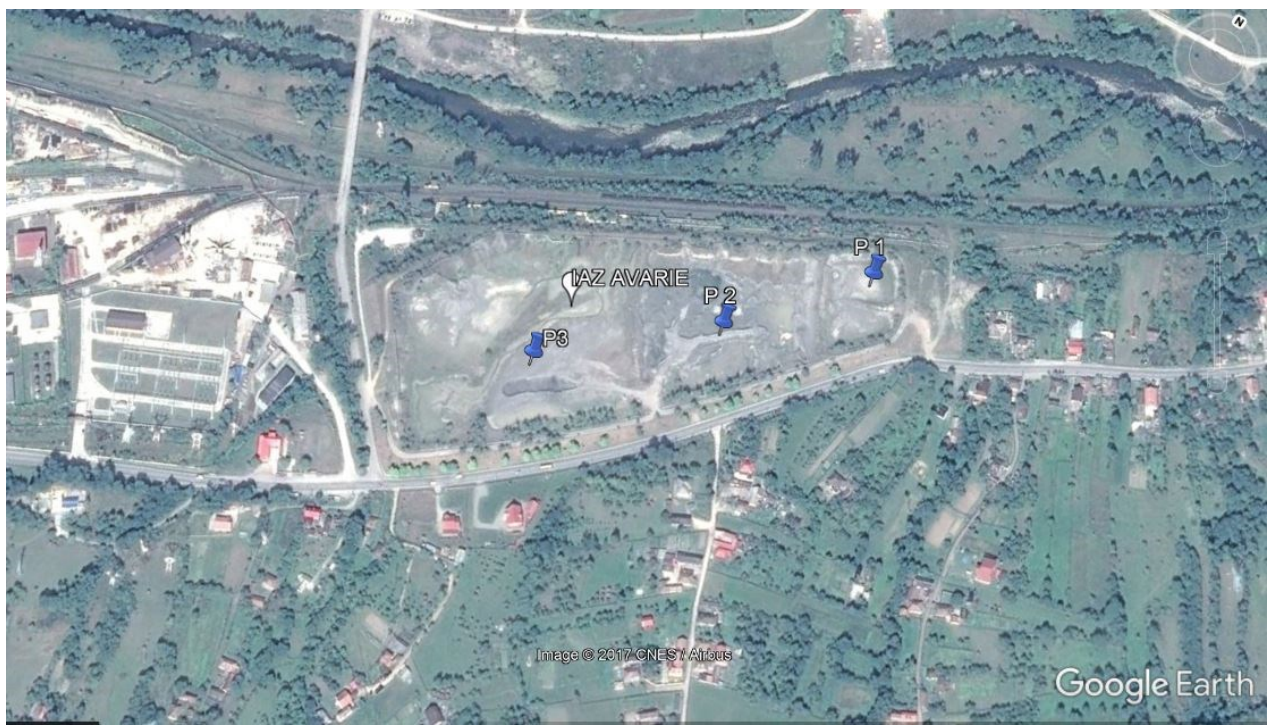

Fig. 3. The sampling points of the analyzed samples from the Emergency pond of the Paroseni Thermal Power Plant

The samples taken were analyzed in the chemistry laboratory of the University of Petrosani. The tests were performed according to STAS 3832/1997. The global chemical analysis of the slag and ash taken from the Emergency pond and the Valea Caprisoara deposit was performed

The results obtained from the analysis are presented in tables 1,2 , and 3 .

Table 1. Results of the global chemical analyzes for the slag and ash taken from the Valea Caprisoara

\begin{tabular}{|l|l|l|l|l|l|l|l|l|l|}
\hline & $\begin{array}{l}\mathrm{SiO} 2 \\
\%\end{array}$ & $\begin{array}{l}\mathrm{CaO} \\
\%\end{array}$ & $\begin{array}{l}\mathrm{MgO} \\
\%\end{array}$ & $\begin{array}{l}\mathrm{Fe} 2 \mathrm{O} 3 \\
\%\end{array}$ & $\begin{array}{l}\mathrm{A} 12 \mathrm{O} 3 \\
\%\end{array}$ & $\begin{array}{l}\mathrm{SO} 3 \\
\%\end{array}$ & $\begin{array}{l}\text { Stotal } \\
\%\end{array}$ & $\begin{array}{l}\text { Na2O } \\
\%\end{array}$ & $\begin{array}{l}\text { K2O } \\
\%\end{array}$ \\
\hline P 1 & 50,18 & 5,11 & 2,27 & 10,1 & 25,3 & 0,5 & 0,8 & 0,83 & 1,19 \\
\hline P 2 & 50,1 & 5,2 & 2,3 & 10,11 & 25,5 & 0,49 & 0,78 & 0,8 & 1,16 \\
\hline P 3 & 49,89 & 5,63 & 2,84 & 9,95 & 24,2 & 0,7 & 0,9 & 0,84 & 1,05 \\
\hline P 4 & 49,2 & 5,6 & 2,3 & 10,24 & 25,28 & 0,66 & 0,81 & 0,79 & 1,3 \\
\hline
\end{tabular}

Table 2. Results of the global chemical analyzes for the slag and ash taken from the Valea Caprisoara

\begin{tabular}{|l|l|l|l|l|l|l|l|l|l|}
\hline \multicolumn{1}{|c|}{} & $\begin{array}{l}\mathrm{SiO} 2 \\
\%\end{array}$ & $\begin{array}{l}\mathrm{CaO} \\
\%\end{array}$ & $\begin{array}{l}\mathrm{MgO} \\
\%\end{array}$ & $\begin{array}{l}\text { Fe2O3 } \\
\%\end{array}$ & $\begin{array}{l}\mathrm{A} 2 \mathrm{O} 3 \\
\%\end{array}$ & $\begin{array}{l}\mathrm{SO} 3 \\
\%\end{array}$ & $\begin{array}{l}\text { Stotal } \\
\%\end{array}$ & $\begin{array}{l}\text { Na2O } \\
\%\end{array}$ & $\begin{array}{l}\text { K2O } \\
\%\end{array}$ \\
\hline P 1 & 49,6 & 5,4 & 2,74 & 9,87 & 23,88 & 0,77 & 0,92 & 0,84 & 1,15 \\
\hline P 2 & 50,08 & 5,1 & 2,23 & 9,9 & 24,6 & 0,54 & 0,86 & 0,82 & 1,2 \\
\hline P 3 & 48,4 & 5,63 & 2,41 & 10,2 & 25,18 & 0,76 & 0,91 & 0,89 & 1,1 \\
\hline P 4 & 49,9 & 5,2 & 2,33 & 10,21 & 25,53 & 0,69 & 0,78 & 0,77 & 1,18 \\
\hline
\end{tabular}

Table 3. Results of the global chemical analyzes for the slag and ash taken from the Emergency pond

\begin{tabular}{|l|l|l|l|l|l|l|l|l|l|}
\hline & $\mathrm{SiO} 2$ & $\mathrm{CaO}$ & $\mathrm{MgO}$ & $\mathrm{Fe} 2 \mathrm{O} 3$ & $\mathrm{Al} 2 \mathrm{O} 3$ & $\mathrm{SO} 3$ & Stotal & $\mathrm{Na} 2 \mathrm{O}$ & $\mathrm{K} 2 \mathrm{O}$ \\
\hline P 1 & 49,9 & 5,13 & 2,69 & 10,5 & 24,23 & 0,67 & 0,9 & 0,72 & 1,21 \\
\hline P 2 & 50,138 & 5,32 & 2,33 & 10,17 & 24,75 & 0,64 & 0,88 & 0,8 & 1,11 \\
\hline P 3 & 49,4 & 5,71 & 2,47 & 10,3 & 25,09 & 0,69 & 0,94 & 0,87 & 1,19 \\
\hline
\end{tabular}


The chemical characteristics of the slag and ash in the tailings ponds of the Paroseni power plant are shown in tables 1,2, and 3. They have the following chemical composition.

By the works of redevelopment of the degraded lands they must be given an economic potential.

The slag and ash deposits could be greened by a naturalistic or productive recultivation.

The costs of rendering slag and ash deposits in the economic circuit are significant. For this reason, methods of productive recultivation have been proposed. By productive recultivation, the environmental costs can be amortized over time.

The choice of ecological reuse is based on the available resources as well as the attitude of the owners and the local community.

Restoration work on degraded land must be given an economic potential. $[4]$

Slag and ash discharges could be ecologized by naturalistic or productive recultivation.

\section{Results and discussion}

The costs of rendering slag and ash deposits in the economic circuit are significant. For this reason, methods of productive recultivation have been proposed. By productive recultivation, greening costs can be amortized over time.

In order to reintroduce the areas in the economic circuit, it is necessary to carry out specific preparation of the land surfaces of the slag and ash deposits. These mandatory procedures are very expensive. In order to compensate over time the costs of preparing the land, we proposed to render in the economic circuit of the land areas by cultivating them with vineyards, namely the vine.

In the case of productive re-cultivation with vines the costs related to the realization of the crop are:

- soil preparation costs,

- costs of acquiring or renting the necessary equipment,

- labor costs,

- purchase costs of vine cuttings, and other planting material,

- maintenance costs over the development period,

- costs for treatments.

After the planting process is completed for a period of 4 years, we will only have the costs of maintenance and treatment. After the first four years the vine begins to become productive, the costs of maintenance and treatment being covered by annual incomes. Also, every year after the development period, a damping of the greening costs will be achieved.

The costs of planting one ha of vine in Romania are shown in Table 1. The table was made in relations with the materials and equipment to be used in the three stages of greening, namely soil preparation for planting, planting and maintenance, the mandatory steps to be taken before the planting of the vine concerning analyzes and treatments, and labor costs. These costs are calculated according to the level of the Romanian market.

Table 4. Total costs related to the planting of one ha of vine in Romania

\begin{tabular}{|l|c|}
\hline \multicolumn{2}{|c|}{ Planting costs in Romania } \\
\hline Type of works & TOTAL (Euro) \\
\hline Cost for land preparation and for planting & 30 Euro \\
\hline Soil analyzes & 400 Euro \\
\hline Applying organic products to increase organic matter and correct $\mathrm{Ph}$ & \\
\hline
\end{tabular}




\begin{tabular}{|l|c|}
\hline Compaction to bury organic matter & 35 Euro \\
\hline Fertilization before planting & 165 Euro \\
\hline Soil preparation & 35 Euro \\
\hline Plantation & \\
\hline Marking for planting & 1000 Euro \\
\hline Planting and irrigation & 4400 Euro \\
\hline Instalation & \\
\hline Installing of the pillars & 2300 Euro \\
\hline Installation of the support & 135 Euro \\
\hline Installation of wire wires, stretchers, poles & 900 Euro \\
\hline Maintenance & \\
\hline Phytosanitary treatment (5 passes) & 55 Euro \\
\hline Total & 9544 Euro \\
\hline Annual maintenance costs & \\
\hline Prunning & 850 Euro \\
\hline Phytosanitary treatment (8 passes) & 142 Euro \\
\hline Total & 992 Euro \\
\hline
\end{tabular}

The costs of making a vine plantation are composed of material costs, mechanization and labor.

The cost of achieving one vineyard plantation per hectare in Romania is 9455 Euro

Once the planting process is completed, the vineyard requires careful maintenance every year. Annual maintenance concerns treatment, prunning and binding. The annual cost per hectare of vine for maintenance is 992 Euro in Romania

The costs of vine planting and maintenance can be amortized by production to the final products after four years.

Four years after planting, the vine becomes productive. Due to the fact that the chemicals in the slag and ash are not transmitted in the fruit beyond the maximum admissible limits, they can be used. Fruits can be sold fresh or for the production of alcoholic and non-alcoholic beverages.

Depending on the type of grape varieties chosen per hectare, between 5,000 and 10,000 liters of wine or juice can be obtained.

This type of reintroduction of the land affected by the deposits has a positive impact on the population in their vicinity. Planting, maintenance and subsequent production will create new jobs.

For the ecologicalization proposed by productive recultivation it is necessary to achieve a layer of vegetal soil of $15-20 \mathrm{~cm}$, which will allow to reduce the phenomenon of scrolling. This layer of vegetal soil will also make a positive contribution to the vegetation development.

The cost of plant soil to cover one hectare of landfill is EUR 24400.

Another method of covering the slag and ash deposits of the thermoelectric power plants is the use of geotextiles. This method can be advantageous due to the fact that at present the availability of vegetal soil is very low. 
According to previous studies, the costs of greening the slag and ash deposits by using geotextile are 59,000 EURO / ha.

The estimated cost of covering clay deposits is 57800 EURO / ha. These greening methods are not a productive greening that provides the opportunity to depreciate these costs.

\section{Conclusions}

Environmental management is an important component of environmental protection.

An environmental management system aims at finding the most effective solutions for complying with environmental protection requirements.

Due to the high cost of redeveloping degraded land resulting from industrial activities, it is necessary to find redevelopment solutions that can be compensatted over time.

The costs of vineyard recultivation of slag and ash deposits are amortized after 4 years of planting.

Planting one hectare of vine may reach costs of 9455 Euro in Romania.

The cost consists of the materials and equipments to be used in the three greening steps, namely soil preparation for planting, planting and maintenance, analyzes and treatments, and labor costs.

Costs presented are calculated according to the level of the Romanian market.

\section{References}

1. Škorecová E., Látečková A., International Scientifis Conference Mmanagerial trends in the development of enterprises in globalization era, (2017).

2. Rojanschi, Vl., Bran F., Grigore, F, Elemente de economia si managementul mediului, Ed. Economică, Bucureşti, (2004).

3. Tataru D., Tataru A. C., Stanci A., Radu S. M., Nan M. S., Lucrările Simpozionului Proceedings of The Symposion SESAM 2015, Volumul 2, pg. 501-506, ISSN 1843-6226, (2015).

4. Tataru D., Tataru A. C., Stanci A., Radu S. M., 7th International Multidisciplinary Symposium „Sustainable Development Through Quality and Innovation in Engineering and Research", (2016) 